\title{
Glucocorticoids are not necessary for the inhibitory effect of endotoxic shock on serum IGF-I and hepatic IGF-I mRNA
}

\author{
T Priego, I Ibáñez de Cáceres, A I Martín', M A Villanúa \\ and A López-Calderón \\ Departamento Fisiología, Facultad de Medicina, Universidad Complutense, 28040 Madrid, Spain \\ 1Departamento Ciencias Morfológicas y Fisiología, Universidad Europea, 28670 Madrid, Spain \\ (Requests for offprints should be addressed to A López-Calderón; Email: ALC@med.ucm.es)
}

\begin{abstract}
The aim of this work was to elucidate the possible role of glucocorticoids in the bacterial lipopolysaccharide (LPS)induced decrease in hepatic IGF-I synthesis. For this purpose, we studied the effect of LPS on IGF-I in two rat strains, Wistar and Lewis, which have different adrenal responses to inflammation. Compared with Wistar rats, Lewis rats have a reduced hypothalamic-pituitary-adrenal response to inflammatory stimuli. Rats received two i.p. injections of $1 \mathrm{mg} / \mathrm{kg}$ LPS and were killed $4 \mathrm{~h}$ after the second injection. LPS induced an increase in serum concentrations of both ACTH and corticosterone, the increase being more pronounced in Wistar than in Lewis rats. LPS decreased hepatic GH receptor (GHR) and IGF-I mRNA only in Wistar rats. However, serum
\end{abstract}

concentrations of IGF-I were significantly decreased $(P<0 \cdot 01)$ in both Wistar and Lewis rats. These data indicate that the adrenal axis may mediate the inhibitory effect of LPS on GHR and IGF-I synthesis in the liver. In a second experiment, adrenalectomized or sham-operated Wistar rats were injected with LPS. Two LPS injections $(0.1 \mathrm{mg} / \mathrm{kg})$ decreased serum concentrations of IGF-I in both type of rat; however, the inhibitory effect of LPS on liver GHR and IGF-I mRNA was observed in adrenalectomized rats, but not in intact rats. All these data suggest that some component of the adrenal axis, other than glucocorticoids, mediates the inhibitory effect of LPS on liver GHR and IGF-I.

Journal of Endocrinology (2002) 172, 449-456

\section{Introduction}

Sepsis can be induced experimentally by administering lipopolysaccharide (LPS), a component of the wall of Gram-negative bacteria, which induces the acute inflammatory response manifested by elevated proinflammatory cytokine release. The initial endocrine response to inflammation and sepsis is characterized by an increase in the activity of the hypothalamic-pituitary-adrenal (HPA) axis and by a decrease in circulating insulin-like growth factor-I (IGF-I) and its synthesis in the liver (Moberg et al. 1971, Fan et al. 1995a). The decrease in anabolic hormones such as IGF-I together with the increase in the release of glucocorticoids might explain the catabolic state observed in sepsis.

The mechanism by which inflammation inhibits the growth hormone (GH)-IGF-I system is not totally known. It has been suggested that the decrease in hepatic IGF-I content during inflammation is mediated by the increased release of cytokines such as interleukin-1 (IL-1) or tumor necrosis factor (TNF). An inhibitory effect of cytokine administration on GH and IGF-I has been demonstrated (Fan et al. 1995b, Peisen et al. 1995), and inhibition of cytokine expression after induction of sepsis increases IGF-I (Fan et al. 1995b). In addition, IL-1 and TNF are also able to inhibit GH-stimulated synthesis of IGF-I and GH receptor (GHR) mRNA in cultured rat hepatocytes (Wolf et al. 1996, Thissen \& Verniers 1997).

Another possibility is that the increased activity of the HPA axis induced by acute endotoxin exposure (Makara et al. 1971, Kakucska et al. 1993) was the mediator of depressed serum and liver IGF-I levels. Glucocorticoids are able to inhibit IGF-I synthesis in the liver (Luo \& Murphy 1989) and in chondrocytes (Jux et al. 1998), and to decrease the GHRs in these organs (Gabrielsson et al. 1995, Jux et al. 1998). However, the influence of glucocorticoids on circulating IGF-I is not well known since elevated plasma IGF-I levels are found in patients with Cushing's syndrome and in rats treated with glucocorticoids (Luo \& Murphy 1989, Bang et al. 1993). Corticotropin-releasing hormone $(\mathrm{CRH})$ can be another of the possible inhibitory factors. It is well known that $\mathrm{CRH}$ administration inhibits pituitary GH secretion possibly by stimulating somatostatin release in both humans and experimental animals (Rivier \& Vale 1985, Raza et al. 1998). 
The aim of this study was to investigate the possible role of hormones of the HPA axis in the inhibition of hepatic and circulating IGF-I during endotoxin shock. For this purpose, we analyzed the IGF-I responses to LPS in Lewis rats with a defective $\mathrm{CRH}$-adrenocorticotropin (ACTH)-corticosterone response to LPS, as well as in rats with the corticosterone response blocked by adrenalectomy.

\section{Materials and Methods}

\section{Animals and experimental protocol}

Male rats were used in all experiments and they were purchased from Charles River (Barcelona, Spain). They were housed three or four per cage, under controlled conditions of temperature $\left(22^{\circ} \mathrm{C}\right)$ and light (lights on from 0730 to $1930 \mathrm{~h}$ ). Food and water were freely available. The procedures followed the guidelines recommended by the European Union for the care and use of laboratory animals.

Ten Wistar and ten Lewis rats (200-250 g; Charles River, Barcelona, Spain) were injected with $1 \mathrm{mg} / \mathrm{kg}$ LPS (serotype 055:B5; Sigma Chemical Co., St Louis, MO, USA) in $250 \mu \mathrm{l}$ sterile saline i.p. at $1730 \mathrm{~h}$ and at $0830 \mathrm{~h}$ the following day. This administration was selected after a previous experiment was performed, looking for the nonlethal LPS dose for Lewis rats able to decrease IGF-I mRNA in the liver of Wistar rats. Control Wistar $(n=10)$ and Lewis rats $(n=10)$ were injected with sterile saline. All animals were killed by decapitation at $1230 \mathrm{~h}, 19 \mathrm{~h}$ after the first and $4 \mathrm{~h}$ after the second LPS or saline injection. Blood was allowed to clot, and the serum was stored at $-20^{\circ} \mathrm{C}$ for IGF-I and corticosterone assays, and at $-80{ }^{\circ} \mathrm{C}$ for ACTH assay. Immediately after decapitation the liver was removed, dissected, frozen in liquid nitrogen and stored at $-80{ }^{\circ} \mathrm{C}$ until RNA extraction and RIA were performed.

In a second set of experiments, 20 Wistar rats (150-200 g) were bilaterally adrenalectomized under light ether anesthesia via a dorsal approach, and 20 control rats were sham operated. Adrenalectomized rats received saline as drinking water supplemented with corticosterone. Corticosterone $(25 \mathrm{mg}$ ) (Sigma) was first dissolved in $2 \mathrm{ml}$ ethanol and after in 11 of saline. Sham-operated rats received $0 \cdot 2 \%$ ethanol in drinking water. Seven days later, half of the animals in each group were injected with $0.1 \mathrm{mg} / \mathrm{kg}$ LPS i.p. at $1730 \mathrm{~h}$ and the day after at $0830 \mathrm{~h}$. The other half were injected with saline and served as control groups. The LPS dose was lower than in the first experiment because adrenalectomized rats survived less than $18 \mathrm{~h}$ after a $1 \mathrm{mg} / \mathrm{kg}$ LPS injection. Since LPS injection decreases food and water intake, adrenalectomized rats received corticosterone at $75 \mathrm{mg} / 1$ in saline as drinking water from the time of the first LPS injection until the end of the experiment (as calculated by the results of a previous pilot study). All rats were killed by decapitation at $1230 \mathrm{~h}$ and serum and liver were collected.

\section{Hormone determination}

Serum and liver IGF-I concentrations were measured by a double-antibody RIA, as described previously (LópezCalderón et al. 1999). The IGF-I antiserum (UB2-495) was a gift from Dr Underwood and Dr Van Wik, and was distributed by the Hormone Distribution Program of the US National Institute of Diabetes, Digestive and Kidney Diseases (NIDDK) (Bethesda, MD, USA) through the National Hormone and Pituitary Program. Levels of IGF-I were expressed in terms of IGF-I A52-EPD-186 standard (Eli Lilly \& Company, Madrid, Spain). The intra-assay coefficient of variation was $8 \%$. All samples from one experiment were run in the same assay.

Serum concentrations of corticosterone were determined by a competitive protein-binding assay (Millán et al. 1996). ACTH levels were measured by RIA with a commercial kit from Diagnostic System Laboratories, Inc. (Webster, TX, USA).

Protein content was measured by Bradford's method (Bradford 1976).

\section{Northern blotting}

Total RNA was extracted by the guanidine thiocyanate method using a commercial kit (Ultraspec RNA; Biotecx Laboratories, Houston, TX, USA). Final RNA concentrations were determined spectrophotometrically at $260 \mathrm{~nm}$. The integrity and the concentration of the RNA were confirmed using agarose gel electrophoresis. For Northern blotting, $20 \mu \mathrm{g}$ denatured RNA from each liver were separated by formaldehyde-agarose gel electrophoresis, transferred to nylon membranes (Hybond-N+, Amersham International, Amersham, Bucks, UK) and fixed by UV crosslinking (Fotodyne, Hartland, WI, USA). To ensure that the same amount of RNA was loaded, the intensities of the $28 \mathrm{~S}$ ribosomal RNA bands in the transferred membranes stained with ethidium bromide were checked.

IGF-I and GHR mRNA hepatic levels were measured by Northern blot hybridization using riboprobes. The rat IGF-I cDNA (Roberts et al. 1987) was generously supplied by Dr LeRoith (Bethesda, MD, USA), and the rat GHR cDNA probe (Baumbach et al. 1989) was kindly provided by Dr Baumbach (Princenton, NJ, USA). To generate radiolabeled complementary RNAs, the plasmid vectors (pGEM-3; Promega, Madison, WI, USA) were linearized with HindIII. The ${ }^{32} \mathrm{P}-$ labeled RNA antisense probes were generated by transcription with T7 RNA polymerase (Roche Molecular Biochemicals, Barcelona, Spain) using $\left[\alpha_{-}{ }^{32} \mathrm{P}\right] \mathrm{CTP}$ (Nuclear Ibérica, Madrid, Spain). Prehybridization was performed for $30 \mathrm{~min}$ at $68^{\circ} \mathrm{C}$ in ULTRAhyb buffer (Ambion, Austin, TX, USA) 
followed by hybridization for $16 \mathrm{~h}$ at the same temperature with $1 \times 10^{6}$ c.p.m. $/ \mathrm{ml}$ labeled IGF-I riboprobe or $2 \times 10^{6}$ c.p.m. $/ \mathrm{ml}$ labeled GHR riboprobe, in the same buffer. The membranes were washed twice with $2 \times$ SSC, $0 \cdot 1 \%$ SDS at $68{ }^{\circ} \mathrm{C}$ for $10 \mathrm{~min}$, and twice with $0 \cdot 1 \times$ SSC, $0.1 \%$ SDS at $68^{\circ} \mathrm{C}$ also for $10 \mathrm{~min}$. IGF-I mRNA transcripts, as visualized by Northern blot analysis, consist of a group of transcripts ranging from $7 \cdot 5$ to $0 \cdot 8 \mathrm{~kb}$. Because all these transcripts may potentially be translated to IGF-I, the densitometric results corresponded to the sum of all IGF-I transcripts. The rat GHR cDNA encodes the GHR and the GH-binding protein (GHBP) mRNA of 4.5 and $1.2 \mathrm{~kb}$; both transcripts were quantified by densitometric analysis and results refer to the total GHR mRNA. To verify loading, control hybridization was performed with a $28 \mathrm{~S}$ DNA probe labeled with $\left[{ }^{32} \mathrm{P}\right] \mathrm{d}-$ CTP by random primer (Roche). The intensities of autoradiogram signal levels were analyzed by densitometric scanning using a PC-Image VGA24 (Foster Findlay Associates Ltd, Newcastle, UK) program for Windows.

\section{Statistical analysis}

Statistics were computed using the statistics program STATGRAPHICS (Statgraphics Consulting S.L., Madrid, Spain) plus for Windows. Statistical significance was calculated by multifactorial ANOVA with LPS and rat strain or adrenalectomy as factors. When the ANOVA indicated a significant interaction between factors, individual means were compared by Duncan's multiple range test. Student's $t$-test was used when comparing only two means. A P-value of less than 0.05 was considered significant.

\section{Results}

Comparison between Wistar and Lewis strain responses to LPS administration

As shown in Fig. 1, two injections of $1 \mathrm{mg} / \mathrm{kg}$ LPS induced a dramatic increase in serum concentrations of ACTH in Wistar rats. Serum concentrations of ACTH were also increased in Lewis rats after LPS, but the increase was much lower than in Wistar rats $(P<0 \cdot 01)$. Serum concentrations of corticosterone were significantly $(P<0 \cdot 01)$ increased by LPS in both rat strains. There were higher corticosterone serum levels in Wistar than in Lewis rats, but the difference was not statistically significant (Fig. 1).

LPS administration to Wistar rats decreased hepatic IGF-I synthesis (Fig. 2). This was reflected by a significant decrease in IGF-I mRNA content in the liver $(P<0 \cdot 01)$ and in hepatic IGF-I content $(P<0 \cdot 01)$ as well as in serum concentrations of IGF-I $(P<0 \cdot 01)$. When comparing Wistar and Lewis rats injected with saline (Fig. 2), Lewis rats had lower serum concentrations of IGF-I $(P<0 \cdot 01)$
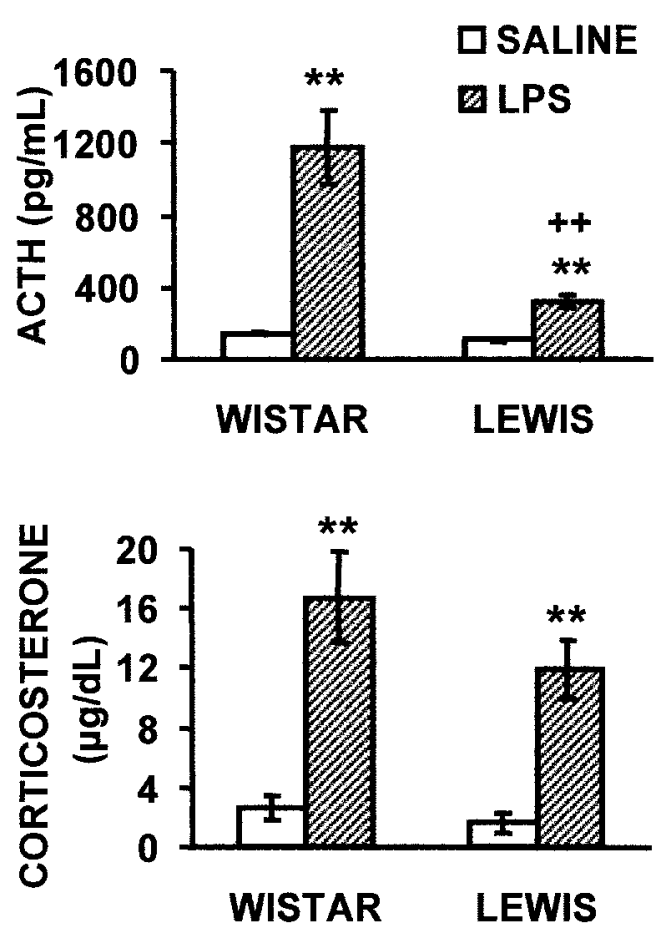

Figure 1 Upper panel: effect of two lipopolysaccharide (LPS) injections ( $1 \mathrm{mg} / \mathrm{kg}$ i.p.) on serum concentrations of $\mathrm{ACTH}$ in Wistar and Lewis rats. LPS administration increased serum concentrations of ACTH $(P<0 \cdot 01)$. There was an interaction $\left(F_{1,33}=12 \cdot 8, P<0 \cdot 01\right)$ between LPS and the rat strain, since the increase in serum ACTH was higher in Wistar than in Lewis rats. Lower panel: serum concentrations of corticosterone were increased after LPS administration $\left(F_{1,33}=45, P<0 \cdot 01\right)$ in both Wistar and Lewis rats. Data represent the means \pm S.E.M. for at least seven rats per group. Statistical analyses were performed using two-way ANOVA ${ }^{* *} P<0 \cdot 01$ vs respective control group injected with saline, ${ }^{++} P<0 \cdot 01$ vs Wistar rats injected with LPS).

and hepatic concentrations of both IGF-I $(P<0 \cdot 01)$ and IGF-I mRNA $(P<0 \cdot 05)$. The inhibitory effect of LPS on the hepatic IGF-I was lower in Lewis than in Wistar rats. Furthermore, the LPS injection did not cause significant differences in hepatic concentrations of IGF-I nor IGF-I mRNA in Lewis rats (Fig. 2). LPS administration decreased serum concentrations of total IGF-I in both Wistar and Lewis rats, but the decrease was lower in Lewis rats $(40 \pm 2 \cdot 2 \%$ of Lewis rats injected with saline vs $30 \pm 2 \cdot 1 \%$ of Wistar rats injected with saline, $P<0 \cdot 05)$. LPS administration to Wistar rats induced a decrease in GHR mRNA in the liver $(P<0 \cdot 01)$, whereas LPS did not modify the gene expression of GHR in the liver in the Lewis rats (Fig. 3).

\section{Effect of adrenalectomy on the IGF-I response to LPS}

In the intact Wistar rats, two $0 \cdot 1 \mathrm{mg} / \mathrm{kg}$ injections of LPS induced a corticosterone response similar to that of a $1 \mathrm{mg} / \mathrm{kg}$ dose (Figs 1 and 4). However, there was a dose 

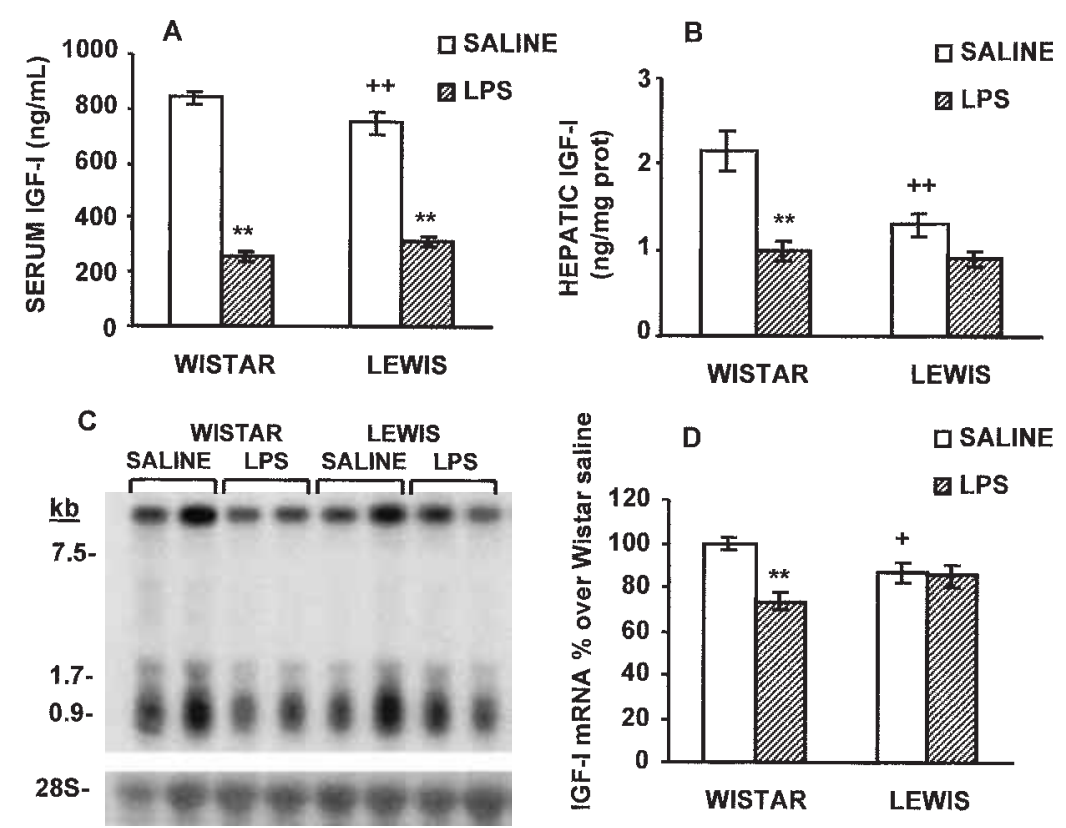

Figure 2 Effect of LPS administration on IGF-I concentrations in serum (A) and in the liver (B) and on IGF-I expression in the liver (D), in Wistar and in Lewis rats. (C) A representative Northern blot of IGF-I mRNA hybridization; $20 \mu \mathrm{g}$ total RNA were hybridized with an RNA probe for rat IGF-I mRNA as described in Materials and Methods. Detectable IGF-I mRNA species are indicated on the left; each lane corresponds to an individual animal from the indicated group, the $28 \mathrm{~S}$ ribosomal RNAs are shown below. Quantitative analyses of two independent Northern blots are expressed as percentages of control Wistar rats injected with saline (D). There was an interaction between the effect of LPS and the rat strain on serum concentrations of IGF-I $\left(F_{1,32}=6, P<0.05\right)$, on hepatic concentrations of IGF-I $\left(F_{1,32}=5 \cdot 98, P<0.05\right)$, and hepatic concentrations of IGF-I mRNA $\left(F_{1,34}=7 \cdot 8, P<0 \cdot 01\right)$ (ANOVA+Duncan multiple comparison test). Each bar represents the mean \pm S.E.M. for at least seven or eight rats. ${ }^{* *} P<0 \cdot 01$ vs respective control group injected with saline, ${ }^{+} P<0 \cdot 05,{ }^{++} P<0 \cdot 01$ vs Wistar rats injected with saline.

response in ACTH increase after LPS, since the increment in serum ACTH levels was smaller after $0.1 \mathrm{mg} / \mathrm{kg}$ than after $1 \mathrm{mg} / \mathrm{kg}$ LPS. Adrenalectomized rats injected with saline had serum levels of corticosterone and ACTH similar to those of the sham-operated rats injected with saline, indicating that the corticosterone dosage in the drinking water was effective. As expected, adrenalectomized rats treated with LPS had lower circulating corticosterone $(P<0 \cdot 01)$ and higher serum ACTH $(P<0 \cdot 01)$ than the sham-operated rats injected with LPS (Fig. 4).

In the Wistar rats, the effect of LPS at the dose of $0.1 \mathrm{mg} / \mathrm{kg}$ on serum and hepatic IGF-I was much lower than at the dose of $1 \mathrm{mg} / \mathrm{kg}$ (Figs 2 and 5). The lower dose $(0 \cdot 1 \mathrm{mg} / \mathrm{kg})$, although it decreased circulating IGF-I, did not modify the hepatic concentrations of either IGF-I or its mRNA in the sham-operated rats. Adrenalectomy seems to potentiate the inhibitory effect of LPS on the hepatic IGF-I mRNA content, since there was a significant decrease $(P<0 \cdot 05)$ in IGF-I mRNA content in adrenalectomized rats, but not in the sham-operated rats, injected with LPS (Fig. 5). Hepatic concentrations of GHR
mRNA were decreased by $0 \cdot 1 \mathrm{mg} / \mathrm{kg}$ LPS (Fig. 6). However, this decrease was not significant when considering the sham-operated or the adrenalectomized rats injected with LPS as individual groups.

\section{Discussion}

Our results confirm previous data indicating that the stimulatory effect of LPS on the pituitary-adrenal axis is more evident in Wistar than in Lewis rats (Perretti et al. 1993). The Lewis strain has a defect in the response of the HPA axis to a variety of immunological stimuli in addition to LPS, such as experimental allergic encephalomyelitis, experimental arthritis and IL-1 (MacPhee et al. 1989, Sternberg et al. 1989, Karalis et al. 1995). The lower adrenal response to LPS in Lewis rats is not due to a deficient cytokine release. On the contrary, the Lewis strain has an overproduction of inflammatory cytokines after LPS administration when compared with the Wistar rat (Perretti et al. 1993). Furthermore, it has been 


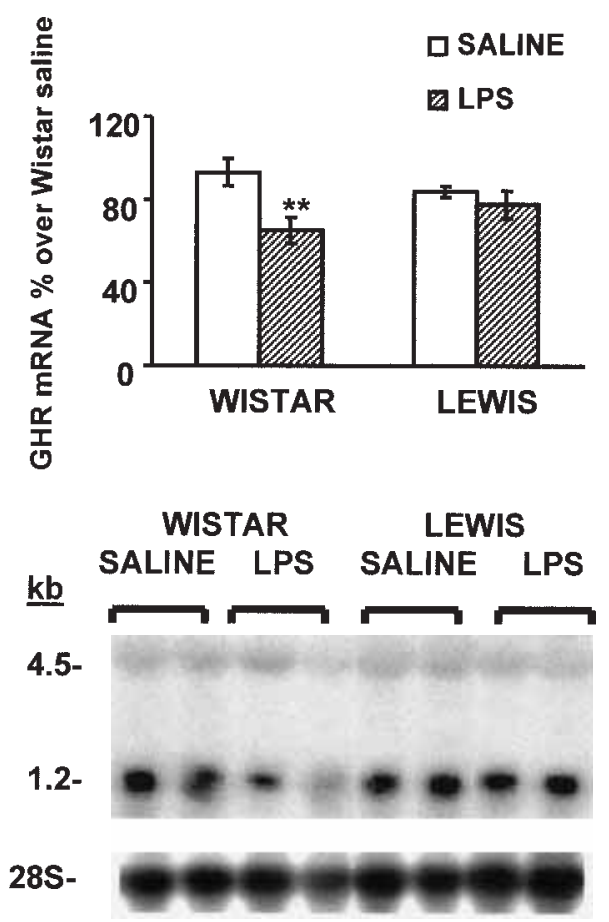

Figure 3 Effect of two injections of LPS ( $1 \mathrm{mg} / \mathrm{kg})$ on the hepatic concentrations of GHR mRNA in Wistar and Lewis rats. Representative Northern blot analyses of total RNA ( $20 \mu \mathrm{g})$ hybridized with a ${ }^{32}$ P-labeled RNA probe encoding the GHR/GHBP common extracellular domain; the $28 \mathrm{~S}$ ribosomal RNAs in each sample are shown below. GHR transcripts are indicated on the left; each lane corresponds to an individual animal from the indicated group. GHR mRNA abundance was determined by densitometry of two independent Northern blots and expressed as a percentage of the mean value of Wistar rats treated with saline. Data represent the means \pm S.E.M. for seven to ten rats per group. ${ }^{* *} P<0 \cdot 01$ vs Wistar rats injected with saline (Duncan's multiple range test).

demonstrated that the hyporesponse of the HPA axis to a variety of stimuli is secondary to a defective CRHsecreting neuron (Calogero et al. 1992).

The inhibitory effect of LPS on circulating levels of IGF-I as well as on the hepatic synthesis of GHR and IGF-I is also lower in Lewis than in Wistar rats. These data suggest that the inhibitory effect of LPS on IGF-I can be mediated by the activation of the adrenal axis rather than by the cytokines release. Another possibility would be that all neuroendocrine responses to LPS administration are lower in Lewis rats than in other rat strains, such as Sprague or Wistar. This does not seem to be the case, since the LPS-induced decrease in thyroxine is higher in Lewis rats than in Sprague-Dawley rats (Whitnall \& Smallridge 1997). Among hormones and peptides of the HPA axis, glucocorticoids do not seem to be responsible for IGF-I inhibition, since adrenalectomy does not only prevent the effect of LPS on IGF-I, but potentiates the effect of LPS on liver IGF-I mRNA. Taking into account that
口SALINE D LPS
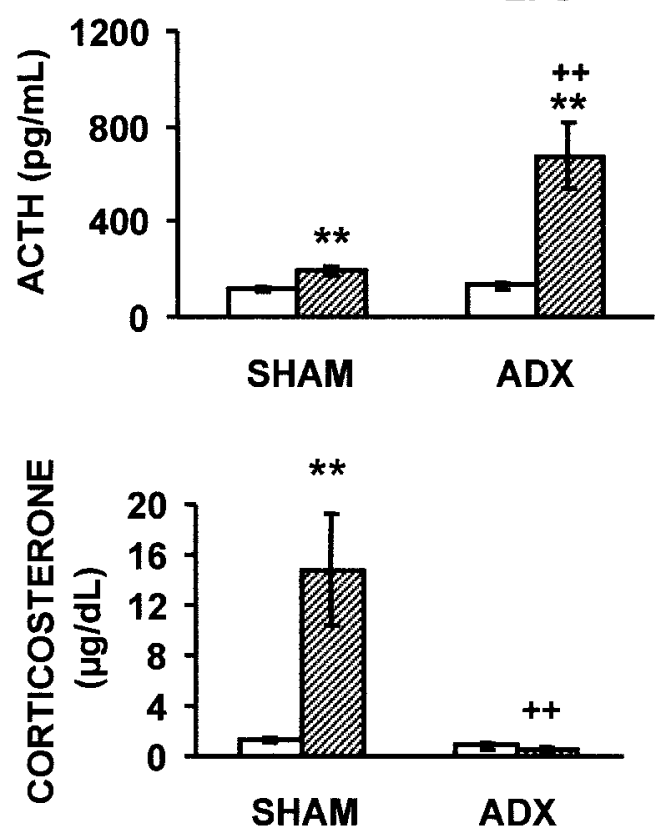

Figure 4 Effect of adrenalectomy upon release of ACTH (upper panel) and corticosterone (lower panel) in adrenalectomized (ADX) and sham-operated (SHAM) rats following two LPS $(0 \cdot 1 \mathrm{mg} / \mathrm{kg})$ injections. There was an interaction $\left(\mathrm{F}_{1,26}=13\right.$, $P<0.01)$ between the effect of LPS and adrenalectomy on circulating $A C T H$, since ADX rats injected with LPS have higher serum concentrations of ACTH than SHAM rats $(P<0 \cdot 01)$. There was also an interaction between the effect of LPS and adrenalectomy on serum corticosterone levels $\left(F_{1,32}=6, P<0 \cdot 05\right)$, since LPS only increases serum concentrations of corticosterone $(P<0.01)$ in SHAM rats. Data represent the means \pm S.E.M. for at least six rats per group. Statistical analyses were performed using two-way ANOVA ( ${ }^{* *} P<0 \cdot 01$ vs respective control group injected with saline, ${ }^{++} P<0 \cdot 01$ vs sham-operated rats injected with LPS).

adrenalectomy also potentiates the ACTH release after LPS injection, other hormones of the HPA axis that are also increased in adrenalectomized rats injected with LPS can mediate the inhibitory effect of LPS on IGF-I. The decrease in IGF-I hepatic production and the decrease in its serum levels in LPS-injected rats seems to be related to the endotoxin-induced GH resistance in the liver. The LPS-induced GH resistance has been previously described as being mediated by a decrease in receptor abundance (Defalque et al. 1999) and by an inhibition of postreceptor signaling through the induction of SOCS genes (Mao et al. 1999). The mechanisms by which LPS inhibits liver GHR mRNA expression seem to be similar to those of IGF-I mRNA, since the liver expression of both genes is affected in a similar way by adrenalectomy or by the rat strain used.

There was a dissociation between the ACTH and corticosterone responses to LPS in Wistar rats, since serum corticosterone was almost maximally activated with the 


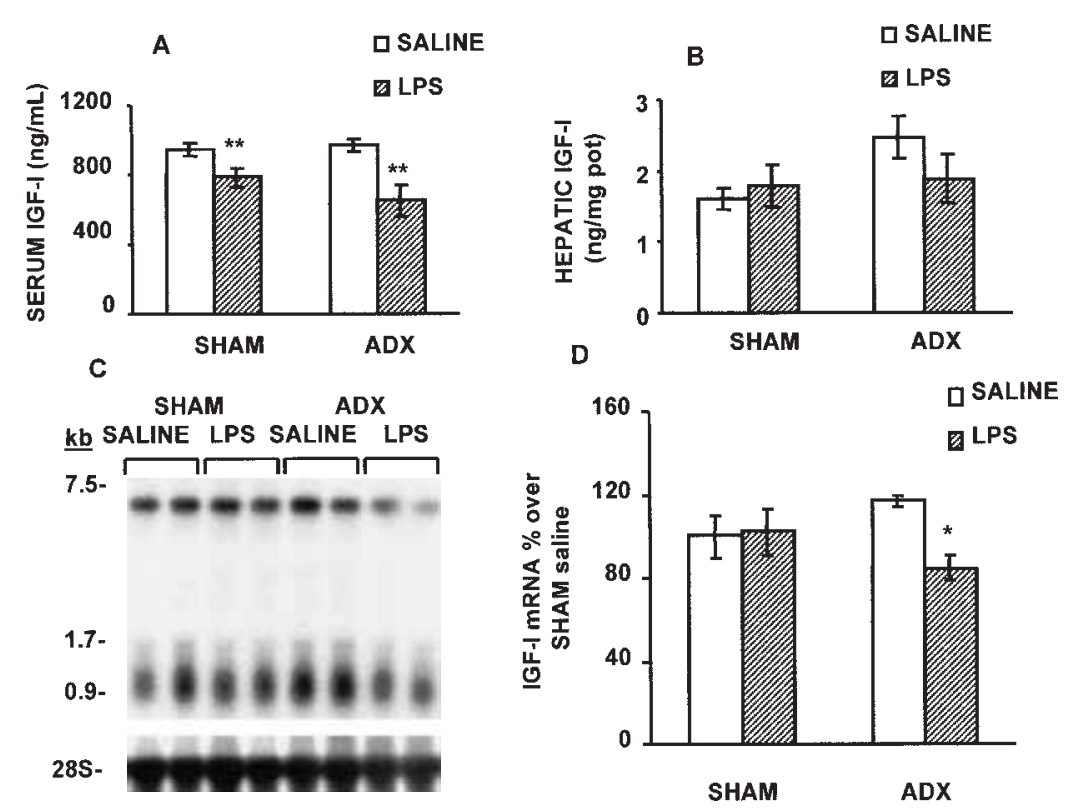

Figure 5 Effect of LPS administration $(0 \cdot 1 \mathrm{mg} / \mathrm{kg})$ on IGF-I concentrations in serum (A) and in the liver (B) and on IGF-I expression in the liver (D), in ADX and SHAM rats. (C) A representative Northern blot of IGF-I mRNA hybridization; $20 \mu \mathrm{g}$ total RNA were hybridized with an RNA probe for rat IGF-I mRNA as described in Materials and Methods. Detectable IGF-I mRNA species are indicated on the left; each lane corresponds to an individual animal from the indicated group, and the $28 \mathrm{~S}$ ribosomal RNA in each sample is shown below. Quantitative analyses of two independent Northern blots are expressed as percentages of SHAM rats injected with saline (D). LPS decreases serum concentrations of IGF-I $\left(F_{1,35}=22, P<0 \cdot 01\right)$ in both SHAM and ADX rats. The IGF-I concentrations of IGF-I mRNA in the liver were decreased $(P<0.01)$ after LPS administration only in ADX rats (two-way +ANOVA Duncan multiple comparison test). Each bar represents the mean \pm S.E.M. for at least six rats. ${ }^{\star} P<0 \cdot 05,{ }^{*} P<0 \cdot 01$ vs their respective control group injected with saline.

two doses used, whereas circulating ACTH had a 2- and 10-fold increase with $0 \cdot 1$ and $1 \mathrm{mg} / \mathrm{kg}$ LPS respectively. This difference in ACTH and corticosterone sensitivity to LPS has been previously described (Derijk et al. 1991). There was also a low IGF-I response to LPS in rats injected with $0.1 \mathrm{mg} / \mathrm{kg}$ LPS, in which the liver IGF-I content was not modified, although the serum concentrations of IGF-I were decreased. Similar data were obtained in Lewis rats injected with the higher LPS dose: the serum concentrations of IGF-I were decreased, while IGF-I and its mRNA in the liver remained unchanged by LPS. The decrease in total serum IGF-I was not due to a postranscriptional mechanism, since the IGF content in the liver of the Lewis rats injected with LPS was not modified. Discordances between serum concentrations of IGF-I and hepatic IGF-I and its mRNA, although in an opposite manner, have been described in rats injected with dexamethasone. Dexamethasone had little effect on serum IGF-I but decreases IGF-I mRNA abundance in the liver (Luo \& Murphy 1989). In normal male volunteers, dexamethasone administration increased circulating IGF-I levels, but reduced the IGF-I bioactivity measured by bioassay (Miell et al. 1993). It has also been reported that glucocorticoid administration in rats increases total serum IGF-I, but decreases serum free IGF-I (Skjaerbaek et al. 1998). A possible explanation for these discrepancies is that the half-life of IGF-I in serum can be regulated in a different way than liver IGF-I synthesis.

It has been previously reported ( $\mathrm{Li}$ et al. 1997) that glucocorticoids play a major role in regulating IGF-I mRNA and peptide content in the liver after LPS administration. The discrepancy between this and our data might be due to different experimental procedures, since those authors used the antiglucocorticoid RU-486 to induce glucocorticoid blockade instead of adrenalectomy. An LPS-induced inhibition of the hypothalamic-pituitarythyroid axis, regardless of corticosteroids, has also been reported (Kondo et al. 1997). Those authors, like us, studied the LPS response in adrenalectomized rats with corticosterone pellet implantation. We can conclude, from our data in the adrenalectomized rats, that glucocorticoids are not necessary for the inhibitory effect of LPS on serum IGF-I and its mRNA in the liver. Moreover, the absence of the increase in glucocorticoid secretion after LPS 

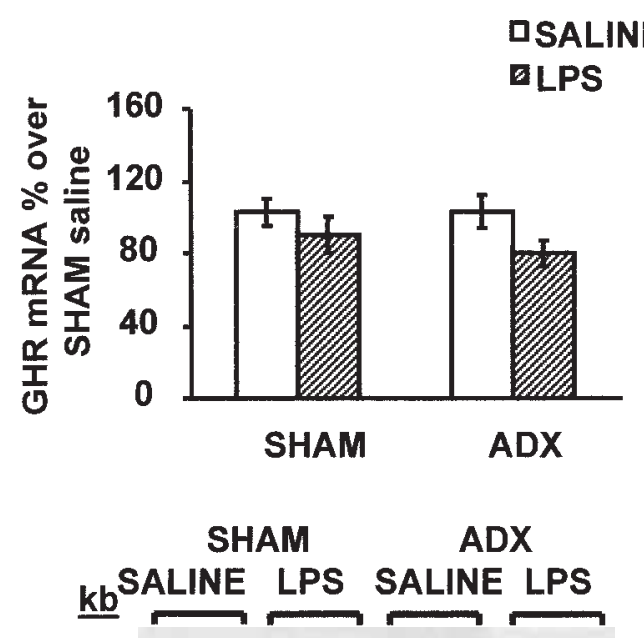

4.5-

$1.2-$

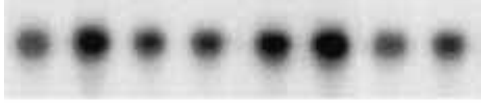

28s-

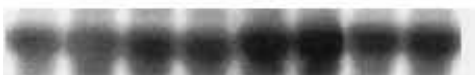

Figure 6 Effect of two injections of LPS $(0 \cdot 1 \mathrm{mg} / \mathrm{kg})$ on the hepatic concentration of GHR mRNA in ADX and SHAM rats. A representative Northern blot analysis of total RNA $(20 \mu \mathrm{g})$ hybridized with a ${ }^{32} \mathrm{P}$-labeled RNA probe encoding the GHR/GHBP common extracellular domain, and the $28 \mathrm{~S}$ ribosomal RNA in each sample is shown below. GHR transcripts are indicated on the left; each lane corresponds to an individual animal from the indicated group, and the $28 \mathrm{~S}$ ribosomal RNA in each sample is shown below. GHR mRNA abundance was determined by densitometry of three independent Northern blots and expressed as a percentage of the mean value of SHAM rats treated with saline. LPS decreases liver concentrations of GHR mRNA $\left(F_{1,35}=4 \cdot 6, P<0 \cdot 05\right)$ (two-way ANOVA). Data represent the means \pm S.E.M. for six to ten rats per group.

administration potentiates the inhibition of liver and serum IGF-I levels.

It has been reported that LPS inhibits pituitary GH secretion by stimulating somatostatin release (Kasting \& Martin 1982, Soto et al. 1998), therefore the effect of LPS on IGF-I can be secondary to a decrease in GH secretion. An increase in pituitary GH mRNA and in the number of GH-releasing hormone $(\mathrm{GHRH})$ receptors (Fife et al. 1996, Tamaki et al. 1996, Korytko \& Cuttler 1997), as well as in GH release (Evans et al. 1982, Casanueva et al. 1990), has been described after glucocorticoid administration. Adrenalectomy in rats decreases GH and GHRH mRNA levels in the pituitary, whereas dexamethasone has the opposite effect (Martinoli \& Pelletier 1989, Lam et al. 1996). All these data indicate that adrenal steroids are necessary for normal GH-IGF-I secretion, although long-term glucocorticoid administration, in a pharmacological dose, has an inhibitory effect on the GH-IGF-I system. The fact that adrenalectomy potentiates the inhibitory effect of LPS on serum and liver IGF-I suggests that glucocorticoids prevent the release of an IGF-I inhibitory factor. CRH can be one of the possible inhibitory factors. It is well known that $\mathrm{CRH}$ administration inhibits pituitary GH secretion possibly by stimulating somatostatin release in both humans and experimental animals (Kasting \& Martin 1982, Peisen et al. 1995, Raza et al. 1998). Data have been previously reported suggesting that $\mathrm{CRH}$ mediates the inhibitory effect of LPS on the somatotropic system (Peisen et al. 1995). This hypothesis also explains that the GH-IGF-I system in Lewis rats, with CRH hyporesponse to LPS, is less affected by LPS than Wistar rats which have normal response.

\section{Acknowledgements}

We thank Dr F Santos from the Department of Pediatrics, Faculty of Medicine, University of Oviedo for his help in the setting-up of the IGF-I and GHR Northern blot. The authors are indebted to A Carmona for technical assistance and to C Bickart for the English correction of the manuscript. We are grateful to Lilly Spain for the IGF-I, and to the US NIDDK National Hormone and Pituitary Program for the reagents for GH and IGF-I determinations. This work was supported by grant from Fondo de Investigaciones Sanitarias de la Seguridad Social (FISS 00/0949) and a Fellowship to H Ibáñez de Cáceres (BEFI, 99/9020).

\section{References}

Bang P, Degerblad M, Thoren M, Schwander J, Blum W \& Hall K 1993 Insulin-like growth factor (IGF) I and II and IGF binding protein (IGFBP) 1, 2 and 3 in serum from patients with Cushing's syndrome. Acta Endocrinologica 128 397-404.

Baumbach WR, Horner DL \& Logan JS 1989 The growth hormonebinding protein in rat serum is an alternatively spliced form of the rat growth hormone receptor. Genes and Development 3 1199-1205.

Bradford MM 1976 A rapid and sensitive method for the quantification of microgram quantities of proteins utilizing the principle of protein-dye binding. Analytical Biochemistry 72 248-254.

Calogero A, Stenberg EM, Bagdy G, Smith C, Bernardini R, Aksentijevich S, Wilder RL, Gold PW \& Chrousos GP 1992 Neurotransmitter-induced hypothalamic-pituitary-adrenal axis responsiveness is defective in inflammatory disease-susceptible Lewis rats: in vivo and in vitro studies suggesting globally defective hypothalamic secretion of corticotropin-releasing hormone. Neuroendocrinology 55 600-608.

Casanueva FF, Burguera B, Muruais C \& Dieguez C 1990 Acute administration of corticoids: a new and peculiar stimulus of growth hormone secretion in man. Journal of Clinical Endocrinology and Metabolism 70 234-237.

Defalque D, Brandt N, Ketelslegers J-M \& Thissen J-P 1999 GH insensitivity induced by endotoxin injection is associated with decreased liver receptors. American Journal of Physiology 276 E565-E572.

Derijk R, Van Rooijen N, Tilders FJH, Besedovsky HO, del Rey A \& Berkenbosch F 1991 Selective depletion of macrophages prevents pituitary-adrenal activation in response to subpyrogenic, but not to 
pyrogenic, doses of bacterial endotoxin in rats. Endocrinology 128 330-338.

Evans RM, Birberg NC \& Rosenfeld MG 1982 Glucocortiocid and thyroid hormones transcriptionally regulate growth hormone gene expression. PNAS 79 7659-7663.

Fan J, Char D, Kolasa AJ, Pan W, Maitra SR, Patlak CS, Spolarics Z, Gelato MC \& Lang CH 1995a Alterations in hepatic production and peripheral clearance of IGF-I after endotoxin. American Journal of Physiology 269 E33-E42.

Fan J, Char D, Bagby GJ, Gelato MC \& Lang CH 1995b Regulation of insulin-like growth factor-I (IGF-I) and IGF-binding proteins by tumor necrosis factor. American Journal of Physiology 269 1204-1212.

Fife SF, Brogan RS, Giustina A \& Wehremberg WB 1996 Immunocytochemical and molecular analysis of the effect of glucocorticoid treatment on the hypothalamic-somatotropic axis in the rat. Neuroendocrinology 64 131-138.

Gabrielsson BG, Carmignac DF, Flavell DM \& Robinson ICAF 1995 Steroid regulation of growth hormone $(\mathrm{GH})$ receptor and $\mathrm{GH}$-binding protein messenger ribonucleic acids in the rat. Endocrinology 136 209-217.

Jux C, Leiber K, Hügel U, Blum W, Ohlsson C, Klaus G \& Mehls O 1998 Dexamethasone impairs growth hormone $(\mathrm{GH})$-stimulated growth by suppression of local insulin-like growth factor (IGF)-I production and expression of GH- and IGF-I-receptor in cultured rat chondrocytes. Endocrinology 139 3296-3305.

Kakucska I, Qi Y, Clark BD \& Lechan RM 1993 Endotoxin-induced corticotropin-releasing hormone gene expression in the hypothalamic paraventricular nucleus is mediated centrally by interleukin. Endocrinology 133 815-821.

Karalis K, Crofford L, Wilder RL \& Chrousos GP 1995 Glucocorticoid and/or glucocorticoid antagonist effects in inflammatory disease-susceptible Lewis rats and inflammatory disease-resistant Fisher rats. Endocrinology 136 3107-3112.

Kasting NW \& Martin JB 1982 Altered release of growth hormone and thyrotropin induced by endotoxin in the rat. American Journal of Physiology 43 E332-E337.

Kondo K, Harbuz MS, Levy A \& Lightman Sl 1997 Inhibition of the hypothalamic-pituitary-thyroid axis in response to lipopolysaccharide is independent of changes in circulating corticosteroids. Neuroimmunomodulation 4 188-194.

Korytko AI \& Cuttler L 1997 Thyroid hormone and glucocorticoid regulation of pituitary growth hormone-releasing hormone receptor gene expression. Journal of Endocrinology 152 R13-R17.

Lam KSL, Lee MF, Tam SP \& Srivastana G 1996 Gene expression of the receptor for growth-hormone-releasing hormone is physiologically regulated by glucocorticoids and estrogen. Neuroendocrinology 63 475-480.

Li YH, Fan J \& Lang CH 1997 Differential role of glucocorticoids in mediating endotoxin-induced changes in IGF-I and IGFBP-1. American Journal of Physiology 272 1990-1997.

López-Calderón A, Soto L \& Martín AI 1999 Chronic inflammation inhibits GH secretion and alters the serum insulin-like growth factor system in rats. Life Sciences 65 2049-2060.

Luo J \& Murphy LJ 1989 Dexamethasone inhibits growth hormone induction of insulin-like growth factor-I (IGF-I) messenger ribonucleic acid (mRNA) in hypophysectomized rats and reduces IGF-I abundance in the intact rat. Endocrinology 125 165-171.

MacPhee IAM, Antoni FA \& Mason DW 1989 Spontaneous recovery of rats from allergic encephalomyelitis is dependent upon regulation of the immune system by endogenous adrenal corticosteroids. Journal of Experimental Medicine 169 431-444.

Makara GB, Stark E \& Meszaros T 1971 Corticotropin release induced by $E$. coli endotoxin after removal of the medial hypothalamus. Endocrinology 88 412-414.

Mao Y, Ling P-R, Fitzgibbons TP, Mc Cowen KC, Frick GP, Bistrian BR \& Smith RJ 1999 Endotoxin-induced inhibition of growth hormone receptor signalling in rat liver in vivo. Endocrinology $1405505-5515$.
Martinoli MG \& Pelletier G 1989 Thyroid and glucocorticoid hormone regulation of rat pituitary growth hormone messenger ribonucleic acid as revealed by in situ hybridization. Endocrinology $1251246-1252$.

Miell JP, Taylor AM, Jones J, Holly JMP, Gaillard RC, Pralong FP, Ross RJM \& Blum WF 1993 The effects of dexamethasone treatment on immunoreactive and bioactive insulin-like growth factors (IGFs) and IGF-binding proteins in normal male volunteers. Journal of Endocrinology 136 525-533.

Millán S, González-Quijano MI, Giordano M, Soto L, Martín AI \& López-Calderón A 1996 Short and long restraint differentially affect humoral and cellular immune functions. Life Sciences 59 1431-1442.

Moberg GP 1971 Site of action of endotoxins on hypothalamicpituitary-adrenal axis. American Journal of Physiology 220 397-400.

Peisen JN, McDonnell KJ, Mulroney SE \& Lumpkin MD 1995 Endotoxin-induced suppression of the somatotropic axis is mediated by interleukin- $1 \beta$ and corticotropin-releasing factor in the juvenile rats. Endocrinology 136 3378-3390.

Perretti M, Duncan GS, Flower RJ \& Peers SH 1993 Serum corticosterone, interleukin-1 and tumour necrosis factor in rat experimental endotoxaemia: comparison between Lewis and Wistar strains. British Journal of Pharmacology 110 868-874.

Raza J, Massoud AF, Hindmarsh PC, Robinson IC \& Brook CG 1998 Direct effects of corticotrophin-releasing hormone on stimulated growth hormone secretion. Clinical Endocrinology 48 217-222.

Rivier C \& Vale W 1985 Involvement of corticotropin-releasing factor and somatostatin in stress-induced inhibition of growth hormone secretion in the rat. Endocrinology 117 2478-2482.

Roberts CT, Lasky SR, Lowe WL, Seaman WT \& LeRoith D 1987 Molecular cloning of rat insulin-like growth factor I complementary deoxyribonucleic acids: differential messenger ribonucleic acid processing and regulation by growth hormone in extra hepatic tissues. Molecular Endocrinology 1 243-248.

Skjaerbaek C, Frystyk J, Orskov H, Kissmeyer-Nielsen P, Jensen MB, Laurberg S, Moller N \& Flyvbjerg A 1998 Differential changes in free and total insulin-like growth factor I after major, elective abdominal surgery: the possible role of insulin-like growth factor-binding protein-3 proteolysis. Endocrinology 83 2445-2449.

Soto L, Martín AI, Millán S, Vara E \& López-Calderón A 1998 Effects of endotoxin lipopolysaccharide administration on the somatotropic axis. Journal of Endocrinology 159 239-246.

Sternberg EM, Hill JM, Chrousos GP, Kamilaris T, Listwak SJ, Gold PW \& Wilder RP 1989 Inflammatory mediator-induced hypothalamic-pituitary-adrenal axis activation is defective in streptococcal cell wall arthritis-susceptible Lewis rats. PNAS $\mathbf{8 6}$ 2374-2378

Tamaki M, Sato M, Marsubara S, Wada Y \& Takahara J 1996 Dexamethasone increases growth hormone $(\mathrm{GH})$-releasing hormone $(\mathrm{GRH})$ receptor mRNA in cultured rat anterior pituitary cells. Journal of Neuroendocrinology 8 475-480.

Thissen JP \& Verniers J 1997 Inhibition by interleukin-1 $\beta$ and tumour necrosis factor- $\alpha$ of the insulin-like growth factor I messenger ribonucleic acid response to growth hormone in rat hepatocyte culture. Endocrinology 138 1078-1084.

Whitnall MH \& Smallridge RC 1997 Altered thyroid axis function in Lewis rats with genetically defective hypothalamic CRH/VP neurosecretory cells. Endocrine Research 23 365-376.

Wolf M, Böhm S, Brand M \& Kreymann G 1996 Proinflammatory cytokines interleukin 1 beta and tumor necrosis factor alpha inhibit growth hormone stimulation of insulin-like growth factor I synthesis and growth hormone receptor mRNA levels in cultured rat liver cells. European Journal of Endocrinology 135 729-737.

Received 25 September 2001

Accepted 25 October 2001 